\title{
Religiosity and emotional intelligence on Muslim student learning achievement
}

\author{
Fikri Farhan', M. Abdul Rofi'ulmuiz ${ }^{2}$ \\ ${ }^{1}$ Department of Management, Faculty of Business, Universitas PGRI Yogyakarta, Indonesia \\ ${ }^{2}$ Department of Management, Faculty of Business and Economics, Universitas Islam Indonesia, Indonesia
}

\begin{tabular}{l} 
Article Info \\
\hline Article history: \\
Received Sep 5, 2020 \\
Revised Mar 12, 2021 \\
Accepted Apr 10, 2021 \\
\hline
\end{tabular}

Keywords:

Emotional intelligence Learning achievement Learning motivation Religiosity

\begin{abstract}
Learning achievement was one of the indicators often used to measure student success in learning. A comprehensive understanding of this topic requires contributions from a variety of disciplines. Recently, researchers are interested in examining the impact of religiosity and emotional intelligence on learning achievement. However, the study on this topic is inconclusive. This study aimed to examine the influence of religiosity and emotional intelligence on learning achievement by learning motivation as a mediating variable. This research was conducted with a quantitative approach. The data was collected through a questionnaire distributed to 122 students of the Management study program, Faculty of Business and Economics, Islamic University of Indonesia. The data was processed using SPSS analysis tools with hierarchical regression analysis techniques. The results demonstrated religiosity and emotional intelligence had a positive impact on learning motivation; learning motivation positively impacted learning achievement. Furthermore, learning motivation mediated the correlation between religiosity and emotional intelligence on learning achievement. The results offer practical implications for campus leaders; Campus leaders should instill religiosity and emotional intelligence in Muslim students to improve their learning achievement.
\end{abstract}

This is an open access article under the $\underline{C C B Y-S A}$ license.

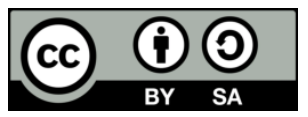

\section{Corresponding Author:}

Fikri Farhan

Department of Management, Faculty of Business

Universitas PGRI Yogyakarta

J1. Sonosewu Baru No.117, Bantul, D.I. Yogyakarta 55184, Indonesia

Email: fikrifarhan@upy.ac.id

\section{INTRODUCTION}

Learning achievement is the student's ability to accept, reject, and assess the information they receive during the learning process. Learning achievement is one indicator that is often used to see student success in the learning process [1]. Usually, learning achievement is stated in grades or report cards for each field of study. Students can see their study results for one semester at the end of their study period [1].

Learning achievement is a topic that is always discussed not only by practitioners and researchers in education but also by researchers in other areas. Various factors influence students' learning achievement [2]. They are usually divided into two elements, namely, internal factors (e.g., psychological and physical) [3] and external (e.g., socio-cultural, parents, school, and the teacher) [4], [5]. Therefore, a comprehensive understanding of this topic requires contributions from a variety of disciplines.

Previous research has shown many factors affect learning achievement, including motivation [6], emotional intelligence [7]-[9], self-efficacy [10], teachers and schools [5], as well as parents' expectations [11]. Recently, researchers are interested in examining the effect of religiosity [12], [13] and emotional 
intelligence [14], [15] on learning achievement. Students who have high levels of religiosity and emotional intelligence are expected to achieve high academic achievements.

However, research conducted by previous researchers [16]-[18] showed there was no notable correlation between religiosity and academic performance. According to Regnerus [19], the direct relationship between these two variables is generally modest in magnitude. The study on this topic is inconclusive concerning the impact of religiosity on academic achievement. Although some studies find that academic achievement of religious students is higher [13], others find it is less [12]. Previous research [15] showed that emotional intelligence improves students' cognitive skills. Besides, emotional intelligence helps a person control harmony and calm in himself and be more confident in facing school and life challenges.

This study added motivation variable as a mediating variable for the correlation between religiosity and emotional intelligence on learning achievement, which has not been widely studied. Besides, Zubairu and Sakariyau [18] suggested further research from his research to examine the effect of religiosity on learning achievement in other Islamic universities because understanding and empirical evidence of these two variables' relationship is still needed.

Additionally, previous studies have not tested the role of learning motivation as a mediating variable on the influence of religiosity and emotional intelligence on learning presentation. In comparison, previous research shows that high religiosity students [20] and emotional intelligence [7] tend to have high learning motivation. Then learning achievement correlates with high learning motivation [6], [21], [22]. Therefore, this study analyzed the impact of religiosity and emotional intelligence on learning achievement with learning motivation as a mediating variable.

\section{LITERATURE REVIEW AND HYPOTHESIS DEVELOPMENT \\ 2.1. Religiosity and learning motivation}

Religiosity is a complex construction, making it difficult to define [23]. The term "religiosity" comes from western traditions that reflect religious phenomena [24]. The word "religiosity," from an etymological point of view, refers to other terms such as "religiosity," "religious," "religion," all of which have their roots in the Latin religio [25]. From a conceptual point of view, religiosity refers to "spirituality," "piety," "obedience," or even "piety." Religiosity refers to various aspects of religious devotion, activity, and belief [13]. Religiosity is awareness of religious importance values and teachings within individual. Individuals with religiosity mean believing in the existence of God, doing what He commands, and showing submission to God [26]. Someone who has religiosity means religious values have been internalized in Him.

Religiosity is a multidimensional phenomenon. There is agreement among researchers that religiosity consists of three integral aspects: affiliation, activity (presence or participation in religious activities), and related beliefs [27]. Glock and Stark [28] conceptualize religiosity consisting of five dimensions, namely: belief (pillars of faith), ritual (prayer, almsgiving, fasting), experience (experiential), intellectual (knowledge of religious teachings and holy texts), and consequential (paying respect to others according to religious teachings).

Religion in Islam is a concept with three essential elements. The first is Islam, which includes one's faithful obligations as meant by acts of prayer; the second is Iman, which represents the system of knowledge and belief in God's understanding; and the third is Ihsan, which represents the realization of ethical and spiritual principles (Sahih al-Bukhari, Vol. 6, Book 60, Number 300, Hadīth 47) [29].

Religion plays an essential role in human life. Religion is believed to influence values, habits, attitudes, and lifestyles [30]. Religiosity is known to influence a person's behavior and various dimensions of life satisfaction and well-being [31]-[33]. Therefore, the effect of religion on human life cannot be denial. In Islam, religion refers to ritual aspects and beliefs, rules, regulations, and moral guidelines for every aspect of human life, including orders for its adherents to become learners.

Islam encourages its adherents to compete in seeking knowledge. Allah would make their path be easy for those treading the path in search of knowledge, leading to Paradise for him. Students who have high religiosity tend to understand Islamic teachings about the importance of gaining knowledge to encourage them to be excited to seek knowledge. Being a Muslim means being an outstanding student. This condition encourages students to study with enthusiasm. Previous research has shown that students who have high religiosity have better learning achievement [19]. Fatima, et al. [20] showed substantial incremental variation in their study findings due to the differential contribution of religiosity factors over demographic and educational factors in predicting Muslim students' motivation to learn. Based on the explanation, the first hypothesis of this study is: Religiosity affects learning motivation. 


\subsection{Emotional intelligence and learning motivation}

Emotional intelligence has been discussed since the early 1940s, along with cognitive intelligence. However, only cognitive intelligence is accepted and responded quickly. The concept of emotional intelligence is developed from the concept of social intelligence [34]. Social intelligence is the capability to comprehend other people [35] and interact well with other people [36].

Emotional intelligence is the capability to recognize and control emotions, whether emotions related to oneself or others. Emotional intelligence is a variety of non-cognitive prowess, capabilities, and competencies affecting a person's ability to cope with environmental demands and pressures [37]. Besides that, emotional intelligence is also the ability of individuals to motivate themselves to be creative and complete work well [34]. Individuals with high emotional intelligence will pay attention to, use, understand, and control emotions. These abilities help an adaptive function, which can potentially serve both themselves and others [38].

Research interest in emotional intelligence is growing in a various of disciplines, from education to physiology to business. Generally, researchers acknowledge the role emotional intelligence plays in a person's success [39]. Goleman [34] addressed IQ contributing just 20 percent to life's achievement and the rest by other causes. These can include social status, luck, and emotional intelligence. Goleman believes emotional intelligence having a more significant IQ impact.

Research from Höpfl and Linstead [40] on their exploratory study of emotions and learning in organizations highlights the importance of studying how children learn and show that children learn content and how to value their work and how to relate to them and how they feel about their teachers and peers. This research reveals that good learning flows through improving logical and emotional skills. Other research conducted by Yahaya, et al. [15] indicates that emotional intelligence contributes to and increases students' cognitive capabilities. Thus, the second hypothesis in this study is: Emotional intelligence affects learning motivation.

\subsection{Learning motivation and academic achievement}

A person's motivation is a force that drives them to act. The questions of why people behave? Why do they work the way they do? Why do they keep doing it or stop doing it? Are answered by motivation. In short, motivation is a mechanism that controls the initiation, strength, and persistence of actions [41]. Motivation is an energetic internal state that contributes to goal-directed behaviors [42].

Someone who is motivated tends to achieve what they want more effectively and efficiently. Besides, motivation can also influence a person in gaining skills and abilities and utilizing them [43]. Likewise, success and happiness tend to be achieved if someone has the motivation to reach them.

Motivation can be seen in various contexts: at home, at work, at school, on the playground, and the athletic field. Sometimes people are motivated by something serious that they are going to do (for example, trying to get a good score on a test), while other times, they are just having fun (for example, trying to run under the sprinkler on a hot day). Although the motivational contexts may differ, the basic idea is the same goal-directed activity [42].

Specifically, in the context of learning, motivation is an encouragement that comes from within and outside the individual, forcing them to achieve excellent learning achievements. In other words, the various challenges that students face to achieve success in learning are influenced by their learning motivation. Furthermore, their motivation influences several success factors in academics, such as students' persistence in doing coursework, their activeness in class discussions, their willingness to be independent learners, and their resilience when facing various obstacles [44]. Academic motivation is defined as enthusiasm for learning achievement, which involves how students have specific behavioral characteristics related to motivation. Thus, students' activeness in the learning process is driven by their motivation, which then impacts their learning achievement.

The motivation for learning is closely associated with learning performance. Besides, one of the determinants of student success and failure in their studies is influenced by motivation. Educators and others believe that motivation influences what students want to learn and how they can understand the lesson [42]. A student having a positive academic motivation level has a will to learn, likes learning-related activities as well as believes that school is essential [45]. Positive academic motivation helps a person to succeed in school and to see that learning is rewarding and vital in life. It is evident from research conducted [6], [21], [46], which shows that learning motivation affects learning achievement. This study indicates that learning motivation has a direct effect on learning achievement. Based on the discussion above, the hypothesis can be formulated as: H3: Learning motivation affects learning achievement; H4: Learning motivation mediates the relationship of religiosity on learning achievement; H5: Learning motivation mediates the relationship between emotional intelligence and learning achievement. The research model of this study can be seen in Figure 1.

Int J Eval \& Res Educ, Vol. 10, No. 2, June 2021: 404 - 411 


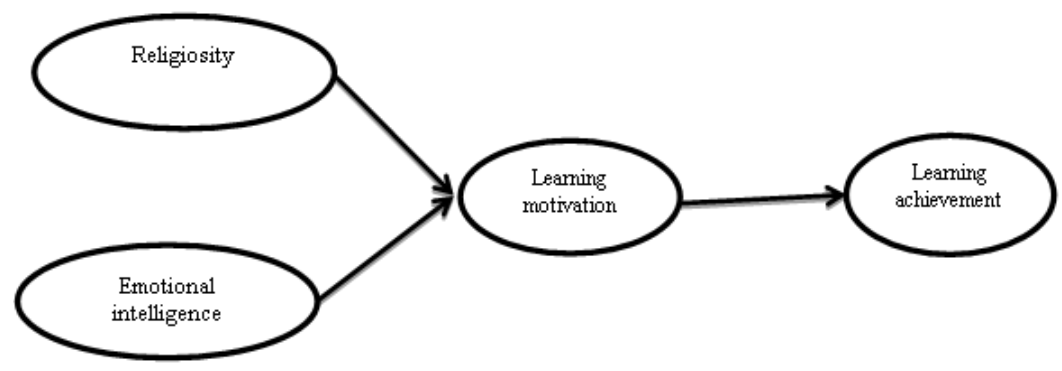

Figure 1. Research model

\section{RESEARCH METHOD}

This study used quantitative methods. The data used was primary data collected by distributing questionnaires to 180 students of the Faculty of Business and Economics, Management Study Program, Islamic University of Indonesia. However, only 122 were worthy of further processing. According to Hair, et al. [47], the minimum sample size is 50 and favorably 100 observations for most research situations. Therefore, the number of samples 122 is a suitable amount for further processing. This sample selection is following the characteristics of the respondents in this study, namely Muslim students. Besides that, every student on this campus gets an education about Islam, even in the learning process has Islamic content.

This study was cross-sectional, which means that data collected at a certain point in time through answers to questions or statements in the questionnaire [48]. Measurement scales of answers in the questionnaire followed the Likert scale. Finally, to test the hypothesis, the data obtained were processed using hierarchical regression analysis. This method was chosen because it can identify a variable's mediating effect in a study [49].

We followed The Baron and Kenny's rule [50] to prove the effect of mediation. Mediation occurred when: 1) The independent variable (X) had a direct and significant impact on the dependent variable $(\mathrm{Y}) ; 2$ ) The independent variable (X) had a direct and significant effect on the mediating variable (M); 3) The mediation variable had a direct and significant effect on the dependent variable; 4) The full mediation effect occurred, if the effect of the independent variable (X) on the dependent (Y) which was initially significant became insignificant when the independent variable $(\mathrm{X})$ and mediation $(\mathrm{M})$ regressed together. Furthermore, partial mediation occurred when the significance of the independent variable $(\mathrm{X})$ increased or decreased to the dependent variable $(\mathrm{Y})$ when the Mediation $(\mathrm{M})$ and independent variables were regressed together.

\section{RESULTS AND DISCUSSION}

\subsection{Respondent's profile}

There were 122 respondents participated in this study. Based on gender, the majority were male students $(61 \%)$. Based on age, most of the respondents were $20-21$ years old $(67 \%)$. Most of the respondents came from Java (72\%). When viewed from the GPA, the highest figures were 3.1-3.5 (44.27\%). Lastly, based on the semester of study, the most dominating was 7 th semester, 50.8\%. Detailed information can be seen in Table 1.

Table 1. Respondent's profile

\begin{tabular}{cccc}
\hline \multicolumn{2}{c}{ Characteristics } & Total & Percentage (\%) \\
\hline \multirow{2}{*}{ Gender } & Male & 75 & 61 \\
& Female & 47 & 39 \\
\multirow{4}{*}{ Age } & $<$ 20 years & 4 & 3 \\
& 20-21 years & 82 & 67 \\
& 22-23 years & 32 & 27 \\
\multirow{5}{*}{ Region } & $>$ 23 years & 4 & 4 \\
& Java & 88 & 72 \\
& Outside Java & 34 & 28 \\
\multirow{4}{*}{ GPA } & $<2.0$ & 2 & 1.63 \\
& $2.0-2.5$ & 5 & 4.10 \\
& $2.6-3.0$ & 16 & 13.11 \\
& $3.1-3.5$ & 54 & 44.27 \\
\multirow{3}{*}{ Semester } & $>3.5$ & 45 & 36.89 \\
& 5 th & 62 & 50.80 \\
& 7 th & 60 & 49.20 \\
\hline
\end{tabular}




\subsection{Hypothesis testing}

The first hypothesis (H1) in this study states that religiosity has a positive effect on learning motivation. The results of the regression analysis showed that religiosity had a positive and significant impact on learning motivation $(\beta=0.373, \mathrm{p}<0.05)$; thus, $\mathrm{H} 1$ is supported. The second hypothesis states that emotional intelligence affects learning motivation. The results of statistical tests showed that emotional intelligence had a positive effect on learning motivation $(\beta=0.750, p<0.05)$. This result meant that $(\mathrm{H} 2)$ in this study is supported. The third hypothesis (H3) states that learning motivation affects learning achievement, the results of data processing showed that learning motivation had a positive effect on learning achievement $(\beta=0.713$, $\mathrm{p}<0.05)$; thus, $\mathrm{H} 3$ is supported.

The fourth hypothesis (H4) in this study is learning motivation mediates the relationship between religiosity on learning achievement. The results of statistical tests showed the following results: 1) There was a positive and significant direct impact of religiosity on learning achievement $(\beta=0.415, p<0.05) ; 2)$ Religiosity had a positive and significant impact on learning motivation $(\beta=0.373, p<0.05)$; 3$)$ Learning motivation had a positive and significant impact on learning achievement $(\beta=0.713, p<0.05)$; 4$)$ The influence of religiosity on learning achievement $(\beta=0.415 \mathrm{p}<0.05)$ changed the regression results after the learning motivation variable was included as mediation $(\beta=0.173, \mathrm{p}<0.05)$. Following Baron and Kenny's rule [50], the learning motivation variable has a partial mediating impact. Thus, the fourth hypothesis learning motivation mediates the impact of religiosity on learning achievement is supported.

The fifth hypothesis (H5) in this study states that learning motivation mediates emotional intelligence on learning achievement. Hypothesis test results showed the following results: 1) There was a positive and significant impact of emotional intelligence on learning achievement $(\beta=0.674, p<0.05) ; 2)$ Emotional intelligence had a positive and significant impact on learning motivation $(\beta=0.750, p<0.05) ; 3)$ Learning motivation had a positive and significant impact on learning achievement $(\beta=0.713, p<0.05) ; 4)$ The impact of emotional intelligence on learning achievement $(\beta=0.674 \mathrm{p}<0.05)$ changed in the regression results after the learning motivation variable was included as mediation $(\beta=0.317, p<0.05)$. Based on the rules of Baron and Kenny [50], the learning motivation variable has a partial mediating impact. Thus, the fifth hypothesis in this study, which states that learning motivation mediates the impact of emotional intelligence on learning achievement, is supported. Detailed information about the results of hypothesis testing can be seen in Table 2.

Table 2. Hypothesis-testing results

\begin{tabular}{lcc}
\hline \multicolumn{1}{c}{ Hypothesis } & Adjusted R square & Standardizes coefficient $(\beta)$ \\
\hline H1 Religiosity $\rightarrow$ learning motivation & .132 & $.373^{* *}$ \\
H2 Emotional intelligence $\rightarrow$ learning motivation & .559 & $.750^{* *}$ \\
H3 Learning motivation $\rightarrow$ learning achievement & .505 & $.713^{* *}$ \\
H4 Religiosity $\rightarrow$ learning achievement & .166 & $.415^{* *}$ \\
Religiosity $\rightarrow$ learning motivation & .132 & $.373^{* *}$ \\
Learning motivation $\rightarrow$ learning achievement & .505 & $.713^{* *}$ \\
Religiosity learning motivation $\rightarrow$ learning achievement & .527 & $.173^{* *}$ \\
& & $.649^{* *}$ \\
H5 Emotional intelligence $\rightarrow$ learning achievement & .449 & $.674^{* *}$ \\
Emotional intelligence $\rightarrow$ learning motivation & .559 & $.750^{* *}$ \\
Learning motivation $\rightarrow$ learning achievement & .505 & $.713^{* *}$ \\
Emotional intelligence learning motivation $\rightarrow$ learning achievement & .545 & $.317^{* *}$ \\
\end{tabular}

\subsection{Discussion}

This study presented empirical evidence about the impact of religiosity and emotional intelligence on learning achievement with learning motivation as a mediating variable. The results of data processing showed that religiosity had a positive impact on learning motivation. Religiosity includes various aspects such as faith, obedience in worship, experience, and knowledge. In short, religiosity refers to the degree to which the devotion of a person to the teachings of his religion, either on the aspect of faith or on the level of practice, represents the commitment in the individual's actions [51].

In Islamic teachings, there is a recognition of the importance of scientific activity. Islam encourages its adherents to compete in seeking knowledge. Allah would make their path be easy for those treading the path in search of knowledge, leading to Paradise for him. Students who have high religiosity tend to understand Islamic teachings about the importance of gaining knowledge to encourage them to be excited to seek knowledge. For Muslim students, learning is a part of worshiping Allah. Besides, they believe that God will elevate knowledgeable people. Thus, they are motivated to learn. These results indicate that the higher 
the religiosity of Muslim students, the higher their learning motivation. The results of this study are in accordance with previous research conducted by Fatima, et al. [20].

Furthermore, this study proved that emotional intelligence had a positive and significant impact on student learning motivation. In education, a student's learning process can be contributed by high emotional intelligence [15], [23]. Students who have emotional intelligence tend to have high learning motivation. High emotional intelligence helps calm and harmonize oneself and finally becomes more confident in completing assignments at school. Previous research has shown that emotional intelligence affects learning motivation [7], [25], [26]. Students who know and deal with their feelings without making those feelings swamp them, feel what the other person is feeling, and handle relationships effectively tend to be able to motivate themselves to do their job well [34]. This study indicated that the higher the students' emotional intelligence, the higher their learning motivation. These results are consistent with research conducted by [7], [52].

This research is also in line with previous research, which proved learning motivation gave a positive and significant impact on learning achievement [22], [46], [53], [54]. This study showed that students with a strong desire for achievement and passion for achieving learning targets and goals would have excellent learning achievements. These results indicated that the higher the student's learning motivation, the higher their learning achievement.

Finally, this study contributed by examining the mediating impact of learning motivation. This study proved that there was a mediating impact on learning motivation. Learning motivation mediated the impact of religiosity on learning achievement. Moreover, learning motivation mediated the impact of emotional intelligence on learning achievement. These results indicated that Muslim students' religiosity and emotional intelligence affected their learning motivation, which in turn affected their learning achievement.

\section{CONCLUSION}

This study proved that in the context of Muslim students, religiosity affected learning motivation. It showed that an increase in religiosity affected an increase in learning motivation. Furthermore, this study confirmed the impact of emotional intelligence on learning motivation too. That meant emotional intelligence was one of the essential variables that will affect motivation to learn. Also, this study indicated that learning motivation affects learning achievement. Students' learning achievement became higher; the stronger their motivation to learn was. Finally, this study proved that learning motivation mediated religiosity and emotional intelligence on learning achievement.

This study's results offer managerial implications suggesting to campus leaders; campus leaders should instill religious values in Muslim students by encouraging them to participate in religious activities or provide facilities such as religious guidance. It was proven in this study that religiosity affected student learning motivation. Besides, the campus leaders should foster students to have high emotional intelligence because it was proven in this study that emotional intelligence affected their learning motivation, which had an impact on increasing their learning achievement.

Otherwise, this study had limitations. Respondents of this study were only students majoring in management at FBE UII. Therefore, for further research, a larger population is needed to increase the generalizability of this study's findings. Moreover, the respondents of this study were students at Islamic colleges. There are Islamic values that become a daily culture in the college. Further research is recommended to examine Muslim students at national universities or other universities with an Islamic identity.

\section{REFERENCES}

[1] C. V. Good, Dictionary of education, 3rd ed. New York: McGraw-Hill, 1973.

[2] P. J. Moore, “Academic achievement," Educ. Psychol., vol. 39, no. 8, pp. 981-983, 2019, doi: 10.1080/01443410.2019.1643971.

[3] I. M. Martínez, C. M. Youssef-Morgan, M. J. Chambel, and A. Marques-Pinto, "Antecedents of academic performance of university students: academic engagement and psychological capital resources," Educ. Psychol., vol. 39, no. 8, pp. 1047-1067, 2019, doi: 10.1080/01443410.2019.1623382.

[4] E. T. Sointu, H. Savolainen, K. Lappalainen, and M. C. Lambert, "Longitudinal associations of student-teacher relationships and behavioural and emotional strengths on academic achievement," Educ. Psychol., vol. 37, no. 4, pp. 457-467, 2017, doi: 10.1080/01443410.2016.1165796.

[5] S. G. Rivkin, E. A. Hanushek, and J. F. Kain, "Teachers, schools, and academic achievement," Econometrica, vol. 73, no. 2, pp. 417-458, 2005, doi: 10.1111/j.1468-0262.2005.00584.x.

[6] S. Areepattamannil and J. G. Freeman, "Academic Achievement, Academic Self-Concept, and Academic Motivation of Immigrant Adolescents in the Greater Toronto Area Secondary Schools," J. Adv. Acad., vol. 19, no. 4, pp. 700-743, 2008, doi: 10.4219/jaa-2008-831. 
[7] D. A. Widyastuti, S. Muyana, and Agungbudiprabowo, "The Effect of Learning Motivation on Student Achievement on Statistics," Proc. 3rd Int. Conf. Educ. Innov. (ICEI 2019), 2020, vol. 227, pp. 386-389, doi: 10.2991/icei-19.2019.81

[8] J. A. Turi, A. A. Rani, I. Abidin, F. Mahmud, and A. Al Adresi, "Correlating spiritual and emotional intelligence with academic performance among Pakistani students," Int. J. Eval. Res. Educ. (IJERE), vol. 9, no. 2, pp. 278-284, 2020, doi: 10.11591/ijere.v9i2.20476.

[9] S. Rajeswari and S. K. Panneer Selvam, "A Study on Students Academic Achievement in Relation to Emotional Intelligence and Spiritual Intelligence of M.Ed Students," Shanlax Int. J. Arts, Sci. Humanit., vol. 7, no. 2, pp. 24-38, 2019, doi: 10.34293/sijash.v7i2.611.

[10] T. Honicke and J. Broadbent, "The influence of academic self-efficacy on academic performance: A systematic review," Educational Research Review, vol. 17, pp. 63-84, Feb. 2016, doi: 10.1016/j.edurev.2015.11.002.

[11] Y. Yamamoto and S. D. Holloway, "Parental expectations and children's academic performance in sociocultural context," Educational Psychology Review, vol. 22, pp. 189-214, 2010, doi: 10.1007/s10648-010-9121-z.

[12] S. Carol and B. Schulz, "Religiosity as a bridge or barrier to immigrant children's educational achievement?" Res. Soc. Stratif. Mobil., vol. 55, pp. 75-88, Jun. 2018, doi: 10.1016/j.rssm.2018.04.001.

[13] B. McKune and J. P. Hoffmann, "Religion and Academic Religion and Academic Achievement Among Adolescents," Faculty Publications, 2009. [Online]. Available: https://scholarsarchive.byu.edu/facpub/3909

[14] K. A. Barchard, "Does Emotional Intelligence Assist in the Prediction of Academic Success," Educ. Psychol. Meas., vol. 63, no. 5, pp. 840-858, 2003, doi: 10.1177/0013164403251333.

[15] A. Yahaya, N. Yahaya, Y. Boon, S. Hashim, and G. Lee, "The impact of emotional intelligence element on academic achievement," Arch. Des Sci., vol. 65, no. 4, pp. 2-16, 2012.

[16] M. Taghavinia and M. Motavassel, "The Relationship between Religiosity and Academic Achievement in Students of Tehran University of Medical Sciences," Iran. J. Med. Educ., vol. 15, pp. 19-26, 2015.

[17] N. Elias, A. Awang, and M. N. Mohamed, "Examining religiosity and its relationship to self-control, procrastination and academic achievement," Malaysian Journal of Learning \& Instruction, vol. 2, pp. 79-93, 2005.

[18] U. M. Zubairu and O. B. Sakariyau, "The Relationship between Religiosity and Academic Performance amongst Accounting Students," Int. J. Eval. Res. Educ. (IJERE), vol. 5, no. 2, pp. 165-173, 2016, doi: 10.11591/ijere.v5i2.4535.

[19] M. D. Regnerus, "Religion and Positive Adolescent Outcomes: A Review of Research and Theory," Rev. Relig. Res., vol. 44, no. 4, pp. 394-413, Nov. 2003, doi: 10.2307/3512217.

[20] S. Fatima, M. Mehfooz, and S. Sharif, "Role of Islamic religiosity in predicting academic motivation of university students," Psycholog. Relig. Spiritual., vol. 9, no. 4, pp. 377-386, 2017, doi: 10.1037/rel0000097.

[21] C. Mega, L. Ronconi, and R. De Beni, "What makes a good student? How emotions, self-regulated learning, and motivation contribute to academic Achievement," J. Educ. Psychol., vol. 106, no. 1, pp. 121-131, 2014, doi: $10.1037 / \mathrm{a} 0033546$

[22] A. Tella, "The impact of motivation on student's academic achievement and learning outcomes in mathematics among secondary school students in Nigeria," Eurasia J. Math. Sci. Technol. Educ., vol. 3, no. 2, pp. 149-156, 2007, doi: 10.12973/ejmste/75390.

[23] B. B. Holdcroft, "What is Religiosity," Cathol. Educ. J. Inq. Pract., vol. 10, no. 1, Sep. 2006. [Online]. Available: https://ejournals.bc.edu/index.php/cej/article/view/733.

[24] A. Runehov and L. Oviedo, Encyclopedia of Sciences and Religions. Springer Netherlands, 2013.

[25] H.-F. Angel, "Religiosity," in Encyclopedia of Sciences and Religions, A. Runehov and L. Oviedo, Eds., Dordrecht: Springer Netherlands, 2013, pp. 2012-2015.

[26] Y. Olufadi, "Muslim Daily Religiosity Assessment Scale (MUDRAS): A new instrument for Muslim religiosity research and practice," Psycholog. Relig. Spiritual., vol. 9, no. 2, pp. 165-179, 2017, doi: 10.1037/rel0000074.

[27] A. Mathur, "Measurement and meaning of religiosity: A cross-cultural comparison of religiosity and charitable giving," J. Targeting, Meas. Anal. Mark., vol. 20, pp. 84-95, 2012, doi: 10.1057/jt.2012.6.

[28] C. Y. Glock and R. Stark, Religion and Society in Tension. San Francisco: Rand McNally and Company, 1965.

[29] "Sahih al-Bukhari, Vol. 6, Book 60, Number 300, Hadìth 47." [Online]. Available: https://sahihbukhari.com/Pages/Bukhari_6_60.php (accessed Oct. 19, 2020).

[30] H. Wright, "YBMs: religious identity and consumption among young British Muslims," Int. J. Mark. Res., vol. 57, no. 1, pp. 151-164, 2015, doi: 10.2501/IJMR-2015-009.

[31] M. M. Poloma and B. F. Pendleton, "Religious domains and general well-being," Soc. Indic. Res., vol. 20, pp. 255-276, 1990, doi: 10.1007/BF00301101.

[32] I. M. Horwitz, "Religion and Academic Achievement: A Research Review Spanning Secondary School and Higher Education," Rev. Relig.s Res., 2020, doi: 10.1007/s13644-020-00433-y.

[33] D. Mathras, A. B. Cohen, N. Mandel, and D. G. Mick, "The effects of religion on consumer behavior: A conceptual framework and research agenda," Journal of Consumer Psychology, vol. 26, no. 2. pp. 298-311, 2016, doi: $10.1016 /$ j.jcps.2015.08.001.

[34] D. Goleman, Emotional Intelligence: Why It Can Matter More Than IQ. London: Bloomsburry Publishing, 1996.

[35] M. L. Barnes and R. J. Sternberg, "Social intelligence and decoding of nonverbal cues," Intelligence, vol. 13, no. 3, pp. 263-287, 1989, doi: 10.1016/0160-2896(89)90022-6.

[36] M. E. Ford and M. S. Tisak, "A further search for social intelligence," J. Educ. Psychol., vol. 75, no. 2, pp. 196-206, 1983, doi: 10.1037/0022-0663.75.2.196.

[37] M. Martinez, "The Smarts That Count," HR Mag., vol. 42, no. 11, p. 72, 1997. 
[38] J. D. Mayer, P. Salovey, and D. R. Caruso, "Emotional Intelligence: New Ability or Eclectic Traits?” Am. Psychol., vol. 63, no. 6, pp. 503-517, 2008, doi: 10.1037/0003-066X.63.6.503.

[39] V. Dulewicz and M. Higgs, "Emotional intelligence A review and evaluation study," J. Manag. Psychol., vol. 15, no. 4, pp. 341-372, 2000, doi: 10.1108/02683940010330993.

[40] H. Höpfl and S. Linstead, "Introduction: Learning to Feel and Feeling to Learn: Emotion and Learning in Organizations," Manag. Learn., vol. 28, no. 1, pp. 5-12, 1997, doi: 10.1177/1350507697281001.

[41] E. L. Usher and D. B. Morris, "Academic Motivation," in Encyclopedia of the Sciences of Learning, N. M. Seel, Ed., Boston, MA: Springer US, 2012, pp. 36-39.

[42] D. Schunk, J. Meece, and P. Pintrich, Motivation in Education Theory, Research and Applications, 4th Ed. Harlow: Pearson Education Limited, 2014.

[43] E. A. Locke and G. P. Latham, "What Should We Do about Motivation Theory? Six Recommendations for the Twenty-First Century," Acad. Manag. Rev., vol. 29, no. 3, pp. 388-403, 2004, doi: 10.2307/20159050.

[44] D. H. Schunk, P. R. Pintrich, and J. R. Meece, Motivation in Education Theory, Research and Applications Dale Schunk Judith Meece Paul Pintrich, 4th Ed. Harlow: Pearson Education Limited, 2014.

[45] M. Güven, "Relation of Motivation and Religiosity: an Empirical Research on the Relation of Academic Motivation and Intrinsic Religious Motivation," EKEV Akad. DERGISI, vol. 17, no. 55, pp. 151-165, 2013.

[46] K. Amrai, S. E. Motlagh, H. A. Zalani, and H. Parhon, "The relationship between academic motivation and academic achievement students," Procedia-Soc. Behav. Sci., vol. 15, pp. 399-402, 2011, doi: 10.1016/j.sbspro.2011.03.111.

[47] J. F. Hair Jr, W. C. Black, B. J. Babin, and R. E. Anderson, Multivariate Data Analysis, 8th Ed. Andover: Cengage Learning EMEA, 2019.

[48] D. R. Cooper and P. S. Schindler, Business Research Methods, 12th ed. New York: McGraw-Hill, 2014.

[49] J. F. Hair, W. C. Black, B. J. Babin, and R. E. Anderson, Multivariate Data Analysis, 7th Ed. New Jersey: Prentice Hall, 2014.

[50] R. M. Baron and D. A. Kenny, "The Moderator-Mediator Variable Distinction in Social The Moderator-Mediator Variable Distinction in Social Psychological Research: Conceptual, Strategic, and Statistical Considerations," J. Pers. Soc. Psychol., vol. 51, no. 6, pp. 1173-1182, 1986, doi: 10.1037/0022-3514.51.6.1173.

[51] B. R. Johnson, D. B. Larson, S. De Li, and S. J. Jang, "Escaping from the crime of inner cities: Church attendance and religious salience among disadvantaged youth," Justice Q., vol. 17, no. 2, pp. 377-391, Jun. 2000, doi: 10.1080/07418820000096371.

[52] R. Dubey, "Emotional intelligence and academic motivation among adolecents: A relationship study," Int. J. Multidiscip. Res., vol. 2, no. 3, pp. 142-147, 2012.

[53] N. Ayub, "Effect of Intrinsic and Extrinsic Motivation on Academic Performance," Pakistan Bus. Rev., vol. 8, pp. 363-372, Jul. 2010.

[54] R. M. Abdelrahman, "Metacognitive awareness and academic motivation and their impact on academic achievement of Ajman University students," Heliyon, vol. 6, no. 9, 2020, doi: 10.1016/j.heliyon.2020.e04192. 